\title{
Characterizing changes in marine ecosystem services
} Kai MA Chan ${ }^{1 *}$ and Mary Ruckelshaus ${ }^{2}$

\author{
Addresses: ${ }^{1}$ Institute for Resources, Environment and Sustainability, University of British Columbia, 2202 Main Mall, Vancouver, BC, V6T 1Z4, \\ Canada; ${ }^{2}$ Marine Initiative of the Natural Capital Project and NOAA Fisheries Northwest Fisheries Science Center, 2725 Montlake Boulevard East, \\ Seattle, WA 98112, USA \\ *Corresponding author: Kai MA Chan (kaichan@ires.ubc.ca) \\ FI000 Biology Reports 2010, 2:54 (doi:10.34I0/B2-54)
}

The electronic version of this article is the complete one and can be found at: http://fl000.com/reports/biology/content/2/54

\begin{abstract}
The benefits of marine ecosystems for people are increasingly being characterized through the concept of ecosystem services, with the promise to aid decision making from marine spatial planning to ecosystem-based management. The characterization of changes in marine ecosystem services is central to the application of ecological science to policy contexts, and this field is quickly evolving with innovations in frameworks for integrating science, understanding of ecosystems and human benefits, and innovations in tools for the modeling of services. In this article, we review efforts to characterize changes in marine ecosystem services, including recent advances, and we propose five key future directions for research: cultural values, qualitative or semi-quantitative modeling approaches, cumulative impacts, model evaluation, and markets.
\end{abstract}

\section{Introduction and context}

What are marine ecosystem services?

Ecosystem services - the processes whereby ecosystems render benefits to people [1] - are becoming the principal means for communicating ecological change in terms of human benefits [2-4]. Understanding ecosystem services is fundamental to decision-making efforts that influence multiple human activities and components of ecosystems, informing management and planning decisions such as the appropriate scale and location of a number of activities. Wise and sustainable decisions of this nature will require a comprehensive understanding of how changes in human activities and ecosystem states will result in changes in ecosystem services and the associated benefits to people [5].

Although much initial research focused on characterizing changes in ecosystem services was rooted in terrestrial and freshwater ecosystems $[6,7]$, ecosystem services has become a central concept in applied marine ecological research and in decision making [8,9]. Examples of marine ecosystem services include provision of seafood for consumption (both farmed and wild), contribution to recreational opportunities, nutrient cycling and filtration of wastes, coastal/natural hazard protection, carbon storage for climate regulation, provision of medium for transport (e.g., shipping), and provision of existence and cultural values $[10,11]$.

\section{Why we need this}

Recent efforts in marine ecosystem-based management (EBM) and marine spatial planning have heightened the calls to characterize changes in or to model (given the emphasis on change and a broad interpretation of modeling [simple representation of a phenomenon], we treat characterizing changes and modeling as synonyms here) ecosystem services under alternative management schemes [9,12-14]. A few examples of EBM efforts in the sea (e.g., Great Barrier Reef Marine Park) approach management of marine resources from an ecosystem perspective aimed at achieving multiple objectives [15]. Even classically single-sector approaches to managing marine resources (e.g., fisheries) increasingly are broadening their scope to include several ecosystem components (e.g., gear impacts on habitat and food webs) and compatibility with activities in other 
sectors (e.g., recreation and shipping) $[9,16,17]$. If interactions between activities can be understood in an ecosystem context through ecosystem service tradeoffs, spatially explicit valuation of possible ecosystem service changes could guide marine spatial planning by informing whether particular tradeoffs are 'worth it'.

Another growing purpose of ecosystem service research is to raise awareness regarding the widespread and valuable nature of ecosystems for humanity. Such communication efforts have contributed to the development of markets for ecosystem services such as storing and sequestering carbon, and more are under development for habitats such as mangroves, which are now included in REDD (reduced emissions from deforestation and degradation) policies. Generally, the demand is increasing for unassailable accounting of changes in ecosystem service 'co-benefits' that accompany ecosystem changes in carbon, biodiversity, and other components (e.g., $[18,19])$.

\section{Academic traditions and development of ideas}

Emerging research on marine ecosystem services draws upon a rich field of research in terrestrial ecosystem services (see Nelson and Daily's F1000 report [20]) and ecosystem-based fisheries management $[16,21]$ and within fields that generally have focused on one or two ecosystem services at a time (e.g., coastal protection and aesthetics). However, whereas terrestrial ecosystem service modeling can be rooted in land use/land cover change and topography (elevation) [7], there is no central and uniting habitat-layer equivalent in marine ecosystems, and connections among locations via flows of nutrients, larvae, and pollutants are both variable and more difficult to discern (Guerry et al., unpublished data). Marine ecosystem service research will need to account for such flows and their complexities [22].

Much early progress on ecosystem services was directed toward appropriate methods of valuation [6]. Because most provisioning services already were associated with marketed goods (e.g., provision of seafood linked to fish sold commercially), they generally have been quantified through market valuation [23]. Regulating services such as mitigation of natural hazards generally have been valued through avoided cost and replacement cost methods, although the latter in particular have been frequently misapplied [6]. Cultural services have proven most contentious to value [24]. Whereas many have not been valued (e.g., contribution to subsistence activities, to artistic experiences, and to ceremonial experiences) [24], tractable valuation methods are emerging for particular services (e.g., travel-cost methods for the contribution to recreational activities, hedonic pricing for the contribution to aesthetic values, and contingent valuation for the provision of existence values) [6].

Although there is no comprehensive body of theory on marine ecosystem services, some important foundational studies include the identification of marine ecosystem services $[10,25]$, demonstration of non-linear responses such as for wave attenuation in a context of multiple ecosystem services in coastal Thailand [26], valuation of the contribution of mangroves to fishery yields in the Gulf of California [27], and relationships between biodiversity and key ecosystem functions such as productivity and nutrient cycling $[28,29]$. The nature of the relationship between biodiversity and ecosystem services continues to be debated [30,31].

\section{Major recent advances}

Early efforts to quantify ecosystem services relied heavily on so-called 'benefit transfer' approaches, in which existing studies valuing ecosystem benefits are applied to other sites, thus enabling the estimation of ecosystem service benefits at new locations [32-35]. Although such approaches are appealing because they are inexpensive and valuation results can be obtained relatively quickly, many applications are fraught with problems, such as transferring benefits to incomparable sites and scaling benefits up from original studies conducted at small scales [36]. Projecting future ecosystem service values is not possible with the benefit-transfer approach without assuming that current correlations between habitat conditions, processes, and values will remain unchanged in the future - assumptions that weaken its applicability in management contexts. There are multiple recent efforts afoot to model marine ecosystem services (Multiscale Integrated Models of Ecosystem Services [MIMES] [37], Artificial Intelligence for Ecosystem Services [ARIES] [38], and the Integrated Valuation of Ecosystem Services and Tradeoffs [InVEST] tool $[7,39])$, and each seems to be improving upon previous approaches in one manner or another. (Because of the newness of these tools, not all of them have been documented in the peerreviewed literature.) For example, ARIES adjusts benefittransfer estimates based on the extent to which services are essential and substitutable [38].

The InVEST tool takes an alternative 'ecological production function' approach that explicitly models how changes in ecosystem structure, function, and processes give rise to changes in ecosystem services $[5,6]$. The production function approach is being developed and applied for a suite of marine ecosystem services by the Marine Initiative of the Natural Capital Project. The Marine InVEST tool quantitatively estimates how climate, management, and policy scenarios specified by users affect ecosystem 
processes, which in turn affect the delivery and socioeconomic value of (a) coastal protection from erosion and inundation provided by abiotic and biogenic habitats, (b) food from fisheries, (c) food from benthic or floating aquaculture, (d) wave energy capture, and (e) recreational activities such as whale watching, beach going, and recreational harvesting of shellfish $[22,40]$.

As the notion of ecosystem services has matured from a concept to an explicitly stated objective in management and policy (e.g., [41-43]), a clear need for distinct metrics of supply, demand, and value of services has emerged (Tallis et al., unpublished data). This has long been recognized in fisheries, where biomass of fish, landed biomass, and market value of fished species have been enumerated and used in bio-economic modeling (e.g., [44]). Applications of such metrics along the supply chain to beneficiaries are less common for other types of services, but there exist approaches to define such metrics for market and non-market goods (Tallis et al., unpublished data and [45]). The need for greater specificity in the underlying models is driven by the need for clear accounting of changes in ecosystem service values in real applications.

Another important advance is the development of frameworks for integrated ecosystem assessment (IEA) $[46,47]$ and EBM $[9,48]$. IEA is an approach rooted in formal decision theory and is intended to provide a foundation for EBM. Such frameworks will be instrumental for characterizing ecosystem service change in support of decision making because they provide a structured approach to handling the dizzying set of choices ecosystem service modelers must make to capture sufficient relevant detail while avoiding overwhelming complexity.

From ecosystem-based fisheries management, representations of fleet dynamics and a value chain approach capture several ecosystem and socioeconomic elements, resulting in a much broader characterization of the socioeconomic value of a fishery $[49,50]$. Such advances will facilitate the extension of traditional trophic models to ecosystem service models. An emerging alternative is the Atlantis model, which is explicitly spatial and includes water quality dynamics and their effects through a food web model; Atlantis also supports sophisticated fleet dynamics, fishing gear details, and feedbacks on the economic value of landings $[51,52]$. The broader inclusion of ecosystem processes positions Atlantis to more easily embrace a suite of ecosystem services which goes beyond fisheries, but its rigidly detailed structure could prevent widespread adoption. The complexity required of these models to realistically represent the effects of fishing on marine ecosystems highlights the tension between (a) complexity for the sake of realism and (b) simplicity and timeliness for relating to decision making.

Developments in visualizing model outputs facilitate selection of decision alternatives that differ along multiple, often incommensurate, dimensions of indicator performance. On this front, the use of tradeoff-visualization approaches borrowed from environmental economics (e.g., [53]) promises to be of some use [54]. For visualizing performance of several decision alternatives across many dimensions of performance, consequence matrices from the decision-analysis literature are likely to be of greater use [55-57].

\section{Future directions}

Cultural ecosystem services represent a considerable gap in ecosystem service modeling. This category of ecosystem services (which includes the contribution to recreational experiences, aesthetic enjoyment, scientific inspiration, and cultural identity) generally has defied quantitative characterization and modeling; tourism (e.g., [58]) and aesthetics (e.g., [59]) are exceptions to this. There is great demand for tools to include such services, but for the many intangible categories of such services, there is as yet no parallel method of characterizing how they will be affected by ecosystem change. Chan and colleagues [24] proposed a very simple framework for spatial modeling of cultural ecosystem services in partnership with local knowledge-holders, but its widespread applicability remains undemonstrated. It is also unclear whether increasingly sophisticated approaches will be possible or culturally appropriate. Kai Chan is co-leading (with Anne Guerry) a working group at the US National Center for Ecological Analysis and Synthesis to help answer such questions.

Ecosystem service modeling will continue to benefit from a broad set of approaches. Ecosystem dynamics which virtually always include both social and ecological subsystems [60] - can become exceedingly complex to model if data-driven, quantitative approaches are the only ones considered. There is a scarcity of data for parameterizing fully quantitative ecosystem models that include species interactions and relationships between drivers of change and ecosystem service change. Factoring in possible synergistic impacts from multiple drivers and non-linearities due to ecological processes that are emergent phenomena of complex systems [61] is likely to be more feasible with qualitative or semi-quantitative approaches $[62,63]$.

A central need in modeling marine ecosystem services is for the inclusion of cumulative impacts: we need a 
greatly improved understanding of how ecosystem states, processes, and functions translate into changes in ecosystem services and how instances of multiple drivers in different places and at different scales combine to produce cumulative impacts on various ecosystem services [54]. Theory suggests that we should expect abundant non-linearities in social-ecological systems [64,65] - so ecosystem service production functions will be a key approach - but we have precious few characterizations of these non-linearities (but see [26]). The mapping of cumulative impacts on ecosystems has increased $[66,67]$, but for ecosystem service research to contribute to decision making, we must quickly advance beyond mapping to the characterization of how these impacts change multiple ecosystem services.

As we develop ecosystem service models based on the best available understanding, there will be a crucial role for evaluating such models. There is some debate about the kind of utility such ecosystem service models have: whether they are or could be predictive in a quantitatively accurate sense (i.e., tactical) or illustrative in a heuristic sense (i.e., strategic or qualitatively informative). Answers to such questions are likely to be scaleand context-dependent, but given the nascent state of our understanding and the complexities inherent in building ecosystem models, we generally see early ecosystem service models as being primarily of qualitative or strategic use. But even for this use, the accuracy of model projections will vary and must be assessed for each model in turn. We argue that such learning should follow as closely as possible a rigorous adaptive management approach [68].

There is great interest in the development of markets for marine ecosystem services (e.g., fishery catch shares, water quality, and nursery habitat protection) [69-72]. So far, there are no good measures or accountability systems for most marine ecosystem services [73], so ecosystem service characterization, quantification, and modeling will be central to these efforts. Although market-oriented efforts for marine conservation are sure to be controversial [74-77], the more fully ecosystem service researchers can characterize ecosystem services and other values at stake in such market efforts (both intended and unintended consequences), the more wisely such market approaches may proceed.

\section{Abbreviations}

ARIES, Artificial Intelligence for Ecosystem Services; EBM, ecosystem-based management; IEA, integrated ecosystem assessment; InVEST, Integrated Valuation of Ecosystem Services and Tradeoffs.

\section{Competing interests}

The authors declare that they have no competing interests.

\section{Acknowledgments}

This paper benefited from reviews by Anne Guerry, Edward Gregr, and Sarah Klain. Recent and ongoing work led by Anne Guerry and Heather Tallis also positively influenced our views.

\section{References}

I. Levine J, Chan KMA: Global human dependence on ecosystem services. In Ecosystem Services and Global Trade of Natural Resources: Ecology, Economics and Policies. Edited by Köllner T. London, UK: Routledge; in press.

2. Daily GC (Ed.): Nature's Services: Societal Dependence on Natural Ecosystems. Washington, DC: Island Press; 1997.

3. Millennium Ecosystem Assessment: Ecosystems and Human Well-Being: Synthesis. Washington, DC: Island Press; 2005.

4. The Economics of Ecosystems and Biodiversity (TEEB) for National and International Policy Makers: United Nations Environment Programme. 2009.

5. Daily GC, Polasky S, Goldstein J, Kareiva PM, Mooney HA, Pejchar L, Ricketts TH, Salzman J, Shallenberger R: Ecosystem services in decision making: time to deliver. Front Ecol Environ 2009, 7:21-8.

6. National Research Council (US) Committee on Assessing and Valuing the Services of Aquatic and Related Terrestrial Ecosystems: Valuing Ecosystem Services: Toward Better Environmental Decision-Making. Washington, DC: National Research Council; 2005:277.

7. Kareiva P, Daily G, Ricketts T, Tallis H, Polasky S: The Theory \& Practice of Ecosystem Service Valuation in Conservation. Oxford, UK: Oxford University Press; in press.

8. Millennium Ecosystem Assessment: Marine and Coastal Ecosystems and Human Well-Being: Synthesis. Washington, DC: Island Press; 2006.

9. McLeod K, Leslie H (Eds.): Ecosystem-Based Management for the Oceans. Washington, DC: Island Press; 2009.

10. Beaumont NJ, Austen MC, Atkins JP, Burdon D, Degraer S, Dentinho TP, Derous S, Holm P, Horton T, van lerland $E$, Marboe AH, Starkey DJ, Townsend M, Zarzycki T: Identification, definition and quantification of goods and services provided by marine biodiversity: implications for the ecosystem approach. Mar Pollut Bull 2007, 54:253-65.

II. Iceland C, Hanson C, Lewis C: Identifying Important Ecosystem Goods \& Services in Puget Sound. Washington, DC: World Resources Institute; 2008:39.

12. Ehler C, Douvere F: Marine Spatial Planning: a step-by-step approach toward ecosystem-based management. In IOC Manual and Guides. Paris, France: United Nations Educational, Scientific and Cultural Organization; 2009.

13. Lubchenco J, Palumbi SR, Gaines SD, Andelman S: Plugging a hole in the ocean: the emerging science of marine reserves. Ecol Appl 2003, 13:S3-S7.

14. Crowder LB, Osherenko G, Young OR, Airamé S, Norse EA, Baron N, Day JC, Douvere F, Ehler CN, Halpern BS, Langdon SJ, McLeod KL, Ogden JC, Peach RE, Rosenberg AA, Wilson JA: Sustainability. Resolving mismatches in US ocean governance. Science 2006, 313:617-8.

I5. Ruckelshaus M, Klinger T, Knowlton N, DeMaster DP: Ecosystembased management in practice: scientific and governance challenges. Bioscience 2008, 58:53-63.

16. Marasco RJ, Goodman D, Grimes CB, Lawson PW, Punt AE, Quinn li T]: Ecosystem-based fisheries management: some practical suggestions. Can J Fish Aquat Sci 2007, 64:928-39.

17. Worm B, Hilborn R, Baum JK, Branch TA, Collie JS, Costello C, Fogarty MJ, Fulton EA, Hutchings JA, Jennings S, Jensen OP, Lotze HK, 
Mace PM, McClanahan TR, Minto C, Palumbi SR, Parma AM, Ricard D, Rosenberg AA, Watson R, Zeller D: Rebuilding global fisheries. Science 2009, 325:578-85.

18. Nelson E, Polasky S, Lewis DJ, Plantingall AJ, Lonsdorf E, White D, Bael D, Lawler JJ: Efficiency of incentives to jointly increase carbon sequestration and species conservation on a landscape. Proc Natl Acad Sci U S A 2008, 105:947I-6.

FI000 Factor 4.8 Must Read

Evaluated by George Malanson 14 Nov 2008, James Wickham 08 Aug 2008

19. Markit Environmental Registry homepage. [http://www.markitenvironmental.com/]

20. Nelson EJ, Daily GC: Modelling ecosystem services in terrestrial systems. Fl000 Biology Reports 2010, 2:53.

21. Pikitch EK, Santora C, Babcock EA, Bakun A, Bonfil R, Conover DO, Dayton P, Doukakis P, Fluharty D, Heneman B, Houde ED, Link J, Livingston PA, Mangel M, McAllister MK, Pope J, Sainsbury KJ: Ecology. Ecosystem-based fishery management. Science 2004, 305:346-7.

22. Guerry AD, Plummer ML, Ruckelshaus MH, Harvey CJ: Ecosystem service assessments for marine conservation. In The Theory \& Practice of Ecosystem Service Valuation in Conservation. Edited by Kareiva P, Daily G, Ricketts T, Tallis H, Polasky S. Oxford, UK: Oxford University Press; in press.

23. Heal G: Nature and the Marketplace: Capturing the Value of Ecosystem Services. Washington, DC: Island Press; 2000.

24. Chan KMA, Goldstein J, Satterfield T, Hannahs N, Kikiloi K, Naidoo R, Vadeboncoeur N, Woodside U: Cultural services and non-use values. In The Theory \& Practice of Ecosystem Service Valuation in Conservation. Edited by Kareiva P, Daily G, Ricketts T, Tallis H, Polasky S. Oxford, UK: Oxford University Press; in press.

25. Peterson $\mathrm{CH}$, Lubchenco J: Marine ecosystem services. In Nature's Services: Societal Dependence on Natural Ecosystems. Edited by Daily GC. Washington, DC: Island Press; 1997:177-94.

26. Barbier EB, Koch EW, Silliman BR, Hacker SD, Wolanski E, Primavera J, Granek EF, Polasky S, Aswani S, Cramer LA, Stoms DM, Kennedy C], Bael D, Kappel CV, Perillo GM, Reed DJ: Coastal ecosystem-based management with nonlinear ecological functions and values. Science 2008, 319:32I-3.

FI000 Factor 3.0 Recommended

Evaluated by Garry Peterson 10 Jun 2008

27. Aburto-Oropeza O, Ezcurra E, Danemann G, Valdez V, Murray J, Sala E: Mangroves in the Gulf of California increase fishery yields. Proc Natl Acad Sci U S A 2008, 105:10456-9.

28. Balvanera P, Pfisterer $A B$, Buchmann $N$, He JS, Nakashizuka $T$, Raffaelli D, Schmid B: Quantifying the evidence for biodiversity effects on ecosystem functioning and services. Ecol Lett 2006, 9:1146-56.

FI000 Factor 6.0 Must Read

Evaluated by George Hurtt 10 May 2007

29. Worm B, Barbier EB, Beaumont N, Duffy JE, Folke C, Halpern BS, Jackson JB, Lotze HK, Micheli F, Palumbi SR, Sala E, Selkoe KA, Stachowicz JJ, Watson R: Impacts of biodiversity loss on ocean ecosystem services. Science 2006, 314:787-90.

FI000 Factor 6.0 Must Read

Evaluated by Andrew Hector 20 Nov 2006

30. Palumbi SR, Sandifer PA, Allan JD, Beck MW, Fautin DG, Fogarty MJ, Halpern BS, Incze LS, Leong J-A, Norse E, Stachowicz JJ, Wall DH: Managing for ocean biodiversity to sustain marine ecosystem services. Front Ecol Environ 2009, 7:204-II.

31. Naeem S, Bunker DE, Hector A (Eds.): Biodiversity, Ecosystem Functioning and Human Wellbeing: An Ecological and Economic Perspective. New York, NY: Oxford University Press; 2009.

32. Costanza R, d'Arge R, de Groot R, Farber S, Grasso M, Hannon B, Limburg K, Naeem S, O'Neill RV, Paruelo J, Raskin RG, Sutton P, van den Belt M: The value of the world's ecosystem services and natural capital. Ecol Econ 1998, 25:3-15.

33. Brouwer R: Environmental value transfer: state of the art and future prospects. Ecol Econ 2000, 32:137-52.

34. Spash CL, Vatn A: Transferring environmental value estimates: issues and alternatives. Ecol Econ 2006, 60:379-88.

35. Troy A, Wilson MA: Mapping ecosystem services: practical challenges and opportunities in linking GIS and value transfer. Ecol Econ 2006, 60:435-49.

36. Plummer ML: Assessing benefit transfer for the valuation of ecosystem services. Front Ecol Environ 2009, 7:38-45.

37. Multiscale Integrated Models of Ecosystem Services (MIMES) homepage. [http://www.uvm.edu/giee/mimes/]

38. Artificial Intelligence for Ecosystem Services (ARIES) homepage. [http://esd.uvm.edu/]

39. Nelson E, Mendoza G, Regetz J, Polasky S, Tallis H, Cameron DR, Chan KMA, Daily GC, Goldstein J, Kareiva PM, Lonsdorf E, Naidoo R, Ricketts TH, Shaw MR: Modeling multiple ecosystem services, biodiversity conservation, commodity production, and tradeoffs at landscape scales. Front Ecol Environ 2009, 7:4-II.

40. Ruckelshaus MH, Guerry AD: Valuing marine ecosystems? Mar Scientist 2009, 26:26-9.

41. Puget Sound Partnership: Draft 2020 Action Agenda for Puget Sound. Olympia, WA: Puget Sound Partnership; 2008:96.

42. Tallis H, Goldman R, Uhl M, Brosi B: Integrating conservation and development in the field: implementing ecosystem service projects. Front Ecol Environ 2009, 7:12-20.

43. Tallis $H$, Kareiva $P$, Marvier $M$, Chang $A$ : An ecosystem services framework to support both practical conservation and economic development. Proc Nat/ Acad Sci U S A 2008, 105:9457-64.

FI000 Factor 3.0 Recommended Evaluated by Elena Bennett 02 Sep 2008

44. Sanchirico JN, Wilen JE: Sustainable use of renewable resources: implications of spatial-dynamic ecological and economic processes. Int Rev Environ Resour Econ 2008, I:367-405.

45. Wainger LA, Boyd JW: Valuing ecosystem services. In EcosystemBased Management for the Oceans. Edited by McLeod K, Leslie H. Washington, DC: Island Press; 2009:92-1II.

46. Dennison WC, Lookingbill TR, Carruthers TJ, Hawkey JM, Carter SL: An eye-opening approach to developing and communicating integrated environmental assessments. Front Ecol Environ 2007, 5:307-14.

47. Levin PS, Fogarty MJ, Murawski SA, Fluharty D: Integrated ecosystem assessments: developing the scientific basis for ecosystem-based management of the ocean. PLoS Biol 2009, 7:el4.

FI000 Factor 3.0 Recommended Evaluated by Kai Chan 12 Mar 2010

48. Tallis H, Levin PS, Ruckelshaus M, Lester SE, McLeod KL, Fluharty DL, Halpern BS: The many faces of ecosystem-based management: making the process work today in real places. Mar Policy 2010, 34:340-8.

49. Christensen V, Walters Cl: Ecopath with Ecosim: methods, capabilities and limitations. Ecol Modell 2004, 172:109-39.

50. Christensen V: MEY = MSY. Fish Fish (Oxf) 2009, I I:105-10.

5I. Fulton EA, Parslow JS, Smith ADM, Johnson CR: Biogeochemical marine ecosystem models, II: the effect of physiological detail on model performance. Ecol Modell 2004, I73:37|-406.

52. Horne P, Kaplan IC, Marshall K, Levin PS, Harvey CJ, Hermann AJ, Fulton EA: Design and parameterization of a spatially explicit ecosystem model of the central California Current. In NOAA Tech Memo. Seattle, WA: Northwest Fisheries Science Center; in press.

53. Nalle DJ, Montgomery CA, Arthur JL, Polasky S, Schumaker NH: Modeling joint production of wildlife and timber.J Environ Econ Manage 2004, 48:997-1017. 
54. Lester SE, McLeod KL, Tallis H, Ruckelshaus M, Halpern BS, Levin PS, Chavez FP, Pomeroy C, McCay BJ, Costello C, Gaines SD, Mace AJ, Barth JA, Fluharty DL, Parrish JK: Science in support of ecosystem-based management for the US West Coast and beyond. Biol Conserv 2010, 143:576-87.

55. Keeney RL, Raiffa H: Decisions with Multiple Objectives. Cambridge, UK: Cambridge University Press; 1993.

56. Patton C, Sawicki DS: Basic Methods of Policy Analysis and Planning. Upper Saddle River, NJ: Prentice Hall; 1993.

57. Failing L, Gregory R, Harstone M: Integrating science and local knowledge in environmental risk management: a decisionfocused approach. Ecol Econ 2007, 64:47-60.

58. Naidoo R, Adamowicz WL: Biodiversity and nature-based tourism at forest reserves in Uganda. Environ Dev Econ 2005, 10:159-78.

59. Gobster PH, Nassauer JI, Daniel TC, Fry G: The shared landscape: what does aesthetics have to do with ecology? Landsc Ecol 2007, 22:959-72.

60. Ostrom E: A general framework for analyzing sustainability of social-ecological systems. Science 2009, 325:419-22.

FI000 Factor 6.0 Must Read

Evaluated by Kai Chan 07 Jun 2010

61. Levin SA: Ecosystems and the biosphere as complex adaptive systems. Ecosystems 1998, I:431-6.

62. Dambacher JM, Brewer DT, Dennis DM, Macintyre M, Foale S: Qualitative modelling of gold mine impacts on Lihir Island's socioeconomic system and reef-edge fish community. Environ Sci Technol 2006, 4I:555-62.

63. Hosack GR, Hayes KR, Dambacher JM: Assessing model structure uncertainty through an analysis of system feedback and Bayesian networks. Ecol Appl 2008, 18:1070-82.

64. Levin SA: Fragile Dominion: Complexity and the Commons. Boston, MA: Perseus Books; 1999.

65. Levin SA, Lubchenco J: Resilience, robustness, and marine ecosystem-based management. Bioscience 2008, 58:27-32.
66. Halpern BS, Walbridge S, Selkoe KA, Kappel CV, Micheli F, D'Agrosa C, Bruno JF, Casey KS, Ebert C, Fox HE, Fujita R, Heinemann D, Lenihan HS, Madin EM, Perry MT, Selig ER, Spalding M, Steneck R, Watson R: A global map of human impact on marine ecosystems. Science 2008, 319:948-52.

FI000 Factor 4.8 Must Read

Evaluated by Peter Kareiva 19 Feb 2008, Russell Moll 28 Feb 2008

67. Halpern BS, McLeod KL, Rosenberg AA, Crowder LB: Managing for cumulative impacts in ecosystem-based management through ocean zoning. Ocean Coast Manag 2008, 5 I:203-II.

68. Walters CJ: Adaptive Management of Renewable Resources. Caldwell, NJ: Blackburn Press; 2002

69. Zwick S, Luke R, Abdulla A, Ness E, Kenny A, Agardy T, Lau W: Paying Poseidon: Financing the Protection of Valuable Ecosystem Services. Washington, DC: Forest Trends; 2010:30.

70. Payments for Ecosystem Services: Getting Started in Marine and Coastal Ecosystems: A Primer. Washington, DC: Forest Trends; 2010:69.

71. The Marine Ecosystem Services (MARES) Program. [http:// |47.202.71.|177/ foresttr/program.php?id=|35]

72. The Chesapeake's Ecosystem Service Marketplace homepage. [http://www.thebaybank.org/]

73. Kroeger T, Casey F: An assessment of market-based approaches to providing ecosystem services on agricultural lands. Ecol Econ 2007, 64:321-32.

74. Norgaard RB: Finding hope in the Millennium Ecosystem Assessment. Conserv Biol 2008, 22:862-9.

75. Rees WE: How should a parasite value its host? Ecol Econ 1998, 25:49-52.

76. Sagoff M: Price, Principle, and the Environment. Cambridge, UK: Cambridge University Press; 2004.

77. Spash CL: How much is that ecosystem in the window? The one with the bio-diverse trail. Environ Values 2008, 17:259-84. 